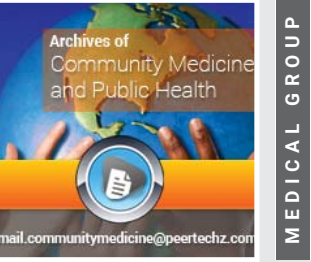

\title{
High-Diluted-Biomedicines Turmeric
}

\author{
Extract (TE) act as Preventive Policy-
}

Developer-Potential-21 ${ }^{\text {st }}$-Century-

\section{Pandemic COVID 19 Vaccines: Achieved}

\section{Community-Communication-Medicine-}

\section{Science-Applications-Public-Health-}

\section{Ecology-Green-Technology-Innovations-}

\section{Economy-Social-Welfare-Issues!}

Received: 26 July, 2021

Accepted: 13 August, 2021

Published: 14 August, 2021

*Corresponding author: Dr. Subhas Chandra Datta, PhD, Ph.D. \& Research from Department of Zoology, VisvaBharati University, Santiniketan, and Headmaster \& Secretary, Kanchannagar D.N.Das High School (HS), Kanchannagar, Burdwan Municipality, Purba Bardhaman, Burdwan-713102, West Bengal, India, Tel: +91 9832192464, +91 7602303924; E-mail: dattasubhas@rediffmail.com,subhaschandra.datta@ gmail.com

ORCID: https://orcid.org/0000-0002-5718-4969

Keywords: High-Diluted-Biomedicines-Turmeric Extract; Preventive-COVID 19-vaccines; AchievedCommunity-Medicine-Public-Health-Ecology; ScienceTechnology-Innovations

https://www.peertechzpublications.com

\section{Check for updates}

\section{Subhas Chandra Datta*}

PhD \& Research from Department of Zoology, VisvaBharati University, Santiniketan and Headmaster \& Secretary, Kanchannagar D.N. Das High School (HS), Kanchannagar, Burdwan Municipality, Purba Bardhaman, Burdwan-713102, West Bengal, India

\begin{abstract}
Introduction: Recently the COVID-19 Coronavirus-Disease-2019 caused by reinfection of the numerous new-mutant-coronavirus long-COVID-19-variant SARS-CoV-2, not only effects on global health, education, clinical research, economy, prolonged-neurological-damage, and total change of human civilization, but also its effects on some organs and tissues in Children causing the 'Multisystem-Inflammatory-Syndrome (MIS-C)' also, and the sixteen-months-pandemic have punctuated humanity's timeline for hundreds of years, sowing panic, millions of infections (188) and killing 4-millions. Though the middle-and upper-classes now enjoying the vaccination, the minority, and low-income households, are really suffering. Still, the pandemic prevails, and the main objectives of the research are to find out suitable cost-effective community-biomedicines or universal vaccines by using high-diluted-form of turmeric extract with the help of local students Non-Governmental-Organization (NGO), and doctors.
\end{abstract}

Methods: In the 11-slam-area, the community-biomedicine of high-diluted-form, Turmeric Extract (TE) or turmeric MT, made from the turmeric-rhizome, Curcuma longa L., is mixed @10-20 drops (1-2mg)/cup (100 ml- $150 \mathrm{ml})$ of moderately-hot germ-free-drinking-water, administered orally every-day in the early morning (with an emptystomach) once/day for thirty-days before illness-onset as a preventive measure, with no need to ethical consideration for the permissible doses and safety concerns, OR may be applied after the symptom-onset against present coronavirus infections as a vaccine, where COVID-19 patients in hospitalized, and also the dose could also be increased looking on the intensity of diseases, and age, just in case of treatment suggested by the doctors, and the young-local-students NGO, the "Burdwan-GreenHaunter-and-Students'-Goal", take initiative for COVID-protocol, social-awareness- and treatment-camp with doctors.

Results: The current preventive-treatment measures have shown that community-biomedicines of high-diluted-TE are more potent in preventing-pathogens by increasing-immunity against COVID-19 with the carcinogenic-free and 'Multisystem-Inflammatory-Syndrome (MIS-C)'-free results in the 11-slam treated-area than anothercontrol-area of Purba Bardhaman, and the NGOs are an active-helper in all respect.

Conclusions: The easily-available, easily-suppliable, easily-applicable, side-effects-free, non-toxic, cost-effective, eco-friendly, easily-preparable, and the 'MIS-C' free high-diluted-potential-community-biomedicine, Turmeric Extract, maybe act as preventive-policy-developer-potential-21st-century-pandemic COVID 19 vaccine by achieving community-medicine-clinical-research-public-health-ecology-green-socio-economy-welfare-science-innovations-technology-communication-applications-issues-advancements. In new normal, it'd be the foremost important vaccines by applying the community-biomedicines of ultra-high-diluted-TE against day-to-day new virulentcoronavirus pandemics, and another multidisciplinary-health-disease suffering from COVID-19 improving community-immunity-or-herd-immunity also, and NGO act as potential-'Social-Vaccines' again, using biotechnology, biological researchers, biomedical-study-processes, and the final goal of future developing-potential-treatments and cures. 


\section{Introduction}

Currently, the COVID-19 coronavirus disease 2019 is caused by reinfection of the numerous new mutant-coronavirus long COVID-19 variant SARS-CoV-2, not only effects on global health, education, clinical research, economy, prolongedneurological-damage, and total change of human civilization, but also its effects on some organs and tissues in Children causing the 'Multisystem-Inflammatory-Syndrome (MIS-C)' also, and the sixteen-months-pandemic have punctuated humanity's timeline for hundreds of years, sowing panic, millions of infections (188), and killing 4-millions. Though the middle-and upper-classes are enjoying the vaccination, the minority and low-income households are really suffering [1-5]. Still, the pandemic prevails, the people are asking regarding changed-research, and the scientists are navigating for the directions by developing policy initiative potential costeffective-universal-vaccines [1-7].

During the visit to the health checkup camp of Kanchannagar D.N.Das High School (HS), Dr. Ranjan Mukherjee, MD from Dr. B.R.A. University, District Coordinator of Sishu Sathi Scheme at Department of Health and Family Welfare, Government, Bardhaman-713101, India, informed me that turmeric is also effective against COVID-19, and it's already well-known that designing the most effective formulation and clinical and molecular mechanisms of curcumin in turmeric shows the new effective treatment option with high efficacy and good bioavailability to treat COVID-19 with high mortality risk, and its several therapeutic effects including antiviral, anti-nociceptive, anti-inflammatory, antipyretic, anti-fatigue, anti-oxidant, anti-apoptotic, anti-fibrotic effects, and inhibitory effects on $\mathrm{NF}-\kappa \mathrm{B}$, inflammatory cytokines and chemokines, toll-like receptors, bradykinin, antidotal or protective effects, and its active ingredient, curcumin, are against natural and chemical toxicities $[8,9]$. It's reported that the potential therapeutic effect of turmeric contents against SARS-CoV-2 compared with experimental COVID-19 therapies, forming 'Wonder Drug as a safety measure for COVID19 Management' because of presence of various immune-boosting phytochemicals i.e. promising potential treatment methods or role of curcumin against this viral diseases or next promising nanosystems antiviral alternatives or the molecular mechanistic insights with relevance host-pathogen interaction and immunomodulation, and therefore the curcumin interact with $S$ protein of SARS CoV2 and ACE2 of human plasma membrane insights from computational studies, and therefore the curcumin-piperine supplementation on clinical signs, duration, severity, and inflammatory factors in patients with COVID-19 in a very structured summary of a study protocol for a randomised controlled trial, and it has proved the near 4000-year history of in-depth medical use in South Asia from the 'Golden Spice, Turmeric, Traditional Medicine to Modern Medicine' [10-20]. But it's created many problems regarding application costeffectiveness, and environmental friendliness, and biodiversity conservation. Currently after the post-COVID situation, within the Burdwan Medical College and Hospital, Purba Bardhaman District, India, reported that 30 children are admitted with the symptoms of 'Multisystem Inflammatory Syndrome (MIS-C)', and badly affected with heart diseases, and one has lost life up to 16 July 2021, BDC News Desk (Figure 1).

Therefore the purpose of the current study is to organize high-diluted OR ultra-high-diluted cost-effective, easily prepare-able, easily available, easily manufacture-able, equitable marketable, and supply-able, community-biomedicine, Turmeric Extract (TE), prepared from the rhizome of turmeric, herbaceous plant, against deadly pandemic new variant and mutant-coronavirus-2 (SARS-CoV-2) patient, with the assistance of the young-energetic-local Non-Governmental-Organization (NGO) named "Burdwan Green Haunter and Students Goal", take initiative or emphasis on the employment of TE among the communities, and different activities of covid-protocol to beat this epidemic situation, and it's planned to publish as suggestions, to require preventive measures, and help policymakers and clinical scientists for community medicine vaccine discovery.

So, the specific, measurable, and consistent main identified research objectives with designs are to find out suitable costeffective community-biomedicines or universal vaccines by using high-diluted-form of turmeric extract with the help of local students Non-Governmental-Organization (NGO), and doctors."

\section{Materials and methods}

\section{Research design}

It is the continuation of work (Figure 1) entitled "NGO Act as Potential-Policy-Developer Social-Vaccine-COVID-19 Epidemic-Model: Achieved Green-Socio-Economic Welfare Science Technology Innovations" [21], where the specific, measurable, and consistent main identified research objectives with designs are to find out suitable cost-effective communitybiomedicines or universal vaccines by using high-dilutedform of turmeric extract with the help of local students NonGovernmental-Organization (NGO), and doctors under the guidance of Dr. Subhas Chandra Datta, Headmaster \& Secretary \& Researcher of Kanchannagar D.N.Das High School (HS)" [21$58]$.

- Medicine Selection

- Sample Groups

- Location of Experiment and Duration

- Different Activity-Groups Formation and Function

- Sample Area

- Biomedicine Turmeric Extract Preparation

- Preparation of Ultra-High-Diluted-BiomedicinesLiquids; Turmeric 30C, Turmeric 200C, and Turmeric 1000C for Future

- Preparation of Ultra-High-Diluted-BiomedicinesGlobules; Turmeric 30C, Turmeric 200C, and Turmeric 1000C for Future 


\section{Daily Press Briefing \\ PurbaBardhaman \\ Date: 11/09/2020 (Up to 5.00 P.M.)}

Part - I: Related to COVID-19

\begin{tabular}{|c|c|c|c|}
\hline i) & $\begin{array}{l}\text { Total No. of COVID Positive Patients found on the } \\
\text { day of reporting * }\end{array}$ & $:$ & 68 \\
\hline ii) & Total no of COVID positive patients** & $:$ & 3339 \\
\hline iii) & Total no of active patients as on today & $:$ & 554 \\
\hline iv) & Total no of discharged cases & $:$ & 2740 \\
\hline v) & Total no of COVID death recorded & $:$ & 45 \\
\hline \multicolumn{4}{|c|}{ - Quarantine status : } \\
\hline vi) & Total no of persons under institutional quarantine & $:$ & 538 \\
\hline vii) & Total no of persons under house quarantine & $:$ & 745 \\
\hline viii) & $\begin{array}{l}\text { Total no of persons under quarantine from } \\
\text { Maharashtra, Delhi, Gujarat, Tamil Nadu \& M.P. }\end{array}$ & $:$ & 733 \\
\hline ix) & $\begin{array}{l}\text { Total no of persons under quarantine from other state } \\
\text { of India }\end{array}$ & $:$ & 27 \\
\hline x) & $\begin{array}{l}\text { Total no of persons relaxed from institutional } \\
\text { quarantine }\end{array}$ & $:$ & 192 \\
\hline \multicolumn{4}{|c|}{ - Testing status : } \\
\hline xi) & Total no of Sample collected up to 10.09 .2020 & $:$ & $\mathbf{7 4 8 3 0}$ \\
\hline xii) & Total no of Sample tested & $:$ & 72899 \\
\hline xiii) & Total no of Positive cases & $:$ & $2149(+41$ repeat $+v e)$ \\
\hline xiv) & Total no of negative Cases & $:$ & 70091(+618spillage/rejected) \\
\hline \multicolumn{4}{|c|}{ - Containment Zone status : } \\
\hline xv) & Total no of Containment Zone as on today & $:$ & 457 \\
\hline xvi) & Total no of containment withdrawn & $:$ & 1259 \\
\hline \multicolumn{4}{|c|}{ - Analysis of Positive Persons Details : On date - Positive- } \\
\hline xvii) & $\begin{array}{l}\text { Total No. of Migrant (Other State + Other Dist. of } \\
\text { WB): }\end{array}$ & $:$ & 2 \\
\hline xviii) & No. of Persons in Safe House: & $:$ & 7 \\
\hline xix) & No. of Person in Covid Hospital: & $:$ & 11 \\
\hline $\mathrm{xx})$ & No. of Persons in Home Isolations: & $:$ & 50 \\
\hline \multicolumn{4}{|c|}{ Analysis on COVID-19 + Ve Cases: } \\
\hline xxi) & Rate of Recovery\# (Percentage) & $:$ & 82.06 \\
\hline xxii) & Rate of Mortality\# (Percentage) & $:$ & 1.34 \\
\hline
\end{tabular}

\section{Daily Press Briefing \\ PurbaBardhaman \\ Date:17/07/2021 (Up to 5.00 P.M.)}

(Report to by send by 7.00 P.M Daily)

Part - I: Related to COVID-19

\begin{tabular}{|c|c|c|}
\hline i) & $\begin{array}{l}\text { Total No. of COVID Positive Patients found on the } \\
\text { day of reporting * }\end{array}$ & $: 22$ \\
\hline ii) & Total no of COVID positive patients" & $: 38225$ \\
\hline iii) & Total no of active patients as on today ${ }^{* * *}$ & $: 449$ \\
\hline iv) & Total no of discharged cases & $: 37331$ \\
\hline v) & Total no of COVID death recorded & $: 445$ \\
\hline \multicolumn{3}{|c|}{ - Quarantine status: } \\
\hline vi) & Total no of persons under institutional quarantine & $: 0$ \\
\hline vii) & Total no of persons under house quarantine & $: 0$ \\
\hline viii) & $\begin{array}{l}\text { Total no of persons under quarantine from } \\
\text { Maharashtra, Delhi, Gujarat, Tamil Nadu \& M.P. }\end{array}$ & $: 0$ \\
\hline ix) & $\begin{array}{l}\text { Total no of persons under quarantine from other } \\
\text { state of India }\end{array}$ & $: 0$ \\
\hline x) & $\begin{array}{l}\text { Total no of persons relaxed from institutional } \\
\text { quarantine }\end{array}$ & $: 0$ \\
\hline \multicolumn{3}{|c|}{ - Testing status: } \\
\hline $\mathrm{xi})$ & Total no of Sample collected up to 16.07 .2021 & $: 290832$ \\
\hline xii) & Total no of Sample tested & $: 290038$ \\
\hline xiii) & Total no of Positive cases & : $15052(+53$ repeat +ve) \\
\hline xiv) & Total no of negative Cases & $:=\begin{array}{l}273741(+1192 \\
\text { spillage/rejected) }\end{array}$ \\
\hline \multicolumn{3}{|c|}{ - Containment Zone status: } \\
\hline$x v)$ & Total no of Containment Zone as on today & $:$ \\
\hline xvi) & Total no of containment withdrawn & $=$ \\
\hline \multicolumn{3}{|c|}{ - Analysis of Positive Persons Details ; On date - Positive- } \\
\hline xvii) & $\begin{array}{l}\text { Total No. of Migrant (Other State }+ \text { Other Dist. of } \\
\text { WB): }\end{array}$ & $: 00$ \\
\hline xviii) & No. of Persons in Safe House: & $: 06$ \\
\hline $\mathrm{xix})$ & No. of Person in Covid Hospital: & $: 02$ \\
\hline $\mathrm{xx})$ & No. of Persons in Home Isolations: & $: 20$ \\
\hline
\end{tabular}

\section{Report on Sample Testing}

\begin{tabular}{|c|c|c|c|}
\hline xxiii) & Antigen Test & $:$ & 1141 \\
\hline xxiv) & RT-PCR Test & $:$ & 758 \\
\hline xiv) & Test Result within $24 \mathrm{Hrs}$. & : & 1141 (RAT-114 + RTPCR- 0 ) \\
\hline
\end{tabular}

\#On Total Positive Case

\section{Part- II:}

Distribution of COVID Positive Cases found on 11/09/2020

[Burdwan Municipality: 11, Dainhat Municipality: 01, Katwa Municipallity: 02, Kalna Municipality:

09, Memari Municipality: 01, Aushgram-I: 01, Aushgram-II: 03, Bhatar: 02, Burdwan-I: 03,

Burdwan-II: 07, Galsi-II: 03, Jamalpur: 01, Kalna-I: 03, Kalna-II: 03, Katwa-I: 01, Khandoghosh:01,

Memari-I: 03, Memari-II: 01, Manteswar: 02, Mongolkote: 01, Purbasthali-I: 02, Purbasthali-II: 05, Raina-II: 02]

Part- III:

\begin{tabular}{|c|l|c|c|}
\hline \multicolumn{2}{|c|}{$\begin{array}{c}\text { Analysis on COVID +Ve Cases on } \\
\mathbf{1 1 . 0 9 . 2 0 2 0}\end{array}$} & $\begin{array}{c}\text { *COVID Positive } \\
\text { as on today }\end{array}$ & **Total Positive Cases \\
\hline \multirow{2}{*}{ Type } & Symptomatic & 11 & 443 \\
\cline { 2 - 4 } & Asymptomatic & 57 & 2896 \\
\hline \multirow{3}{*}{$\begin{array}{c}\text { Contact } \\
\text { Analysis }\end{array}$} & Total & $\mathbf{6 8}$ & $\mathbf{3 3 3 9}$ \\
\cline { 2 - 4 } & Trimary Contact & 15 & 510 \\
\cline { 2 - 4 } & Travel from High Burden Dist. of W.B. & 2 & 170 \\
\cline { 2 - 4 } & No Travel History & 0 & 405 \\
\hline \multicolumn{2}{|c|}{ Total } & 51 & 2254 \\
\hline
\end{tabular}

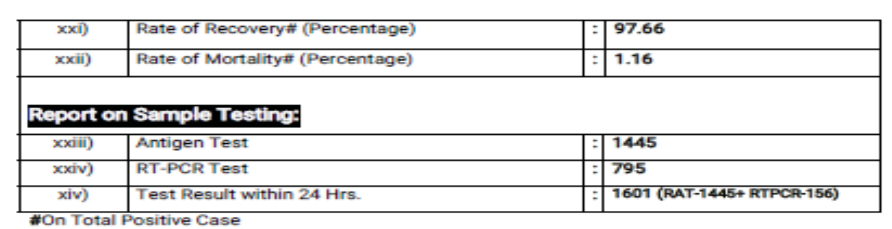

Part- II:

Distribution of COVID Positive Cases found on 17/07/2021

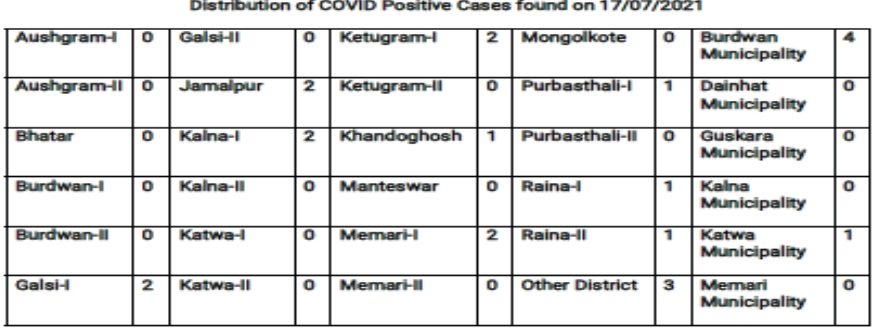

\begin{tabular}{|c|c|c|c|}
\hline \multicolumn{2}{|c|}{$\begin{array}{l}\text { Analysis on COVID +Ve Cases on } \\
17 / 07 / 2021\end{array}$} & \multirow{2}{*}{$\begin{array}{c}\text { *ovid Positive } \\
\text { as on today }\end{array}$} & \multirow{2}{*}{$\begin{array}{c}- \text { Total Posinive Cases } \\
2724\end{array}$} \\
\hline & Symptomatic & & \\
\hline Type & Asymptomatic & 20 & 35501 \\
\hline \multirow{5}{*}{$\begin{array}{l}\text { Contact } \\
\text { Analysis }\end{array}$} & Total & 22 & 38225 \\
\hline & \begin{tabular}{|l|} 
Primary Contact \\
\end{tabular} & 00 & 1520 \\
\hline & Travel from High Burden Dist. of W.B. & 00 & 217 \\
\hline & Travel from Other State & 00 & 435 \\
\hline & No Travel History & 22 & 36053 \\
\hline & Total & 22 & 38225 \\
\hline
\end{tabular}


- Treatments

- Collection Methods of Data and Maintenance Records

$\checkmark$ Observations

- Science and Technology Communication

- Full protocol.

\section{Medicine selection}

During the visit to the health checkup camp of Kanchannagar D.N.Das High School (HS), Dr. Ranjan Mukherjee, MD from Dr. B.R.A. University, District Coordinator of Sishu Sathi Scheme at Department of Health and Family Welfare, Government, Bardhaman-713101, India, informed the headmaster that turmeric is also effective against COVID-19 like ginger $[44,46,47,51,54]$. So, high-diluted form of turmeric extract is selected for preventive treatment measures.

\section{Sample groups}

Total preventive treatment sample groups have considered 1907-families participating in 12315-members, and the criteria are the resident of 11-slam areas with below poverty. The rest of the total populations of the Burdwan Municipality and its surrounding of Purba Bardhaman District, West Bengal, India, act as the control group (without treatment with a high-diluted form of turmeric extract (Figure 1 \& Plate 1) [44,46,47,51,54].

\section{Location of experiment and duration}

The study was dole out by the doctors, headmaster, and young-local-Non-Governmental-Organization (NGO) named "Burdwan-Green-Haunter and Students'-Goal", at the 11slam area of Purba Bardhaman District, India. Total families were 1907 and also the total population was 12315, and therefore the activities were conducted and measured from the 11th September 2020 to 17th July 2021and up-to-date (Figure 1

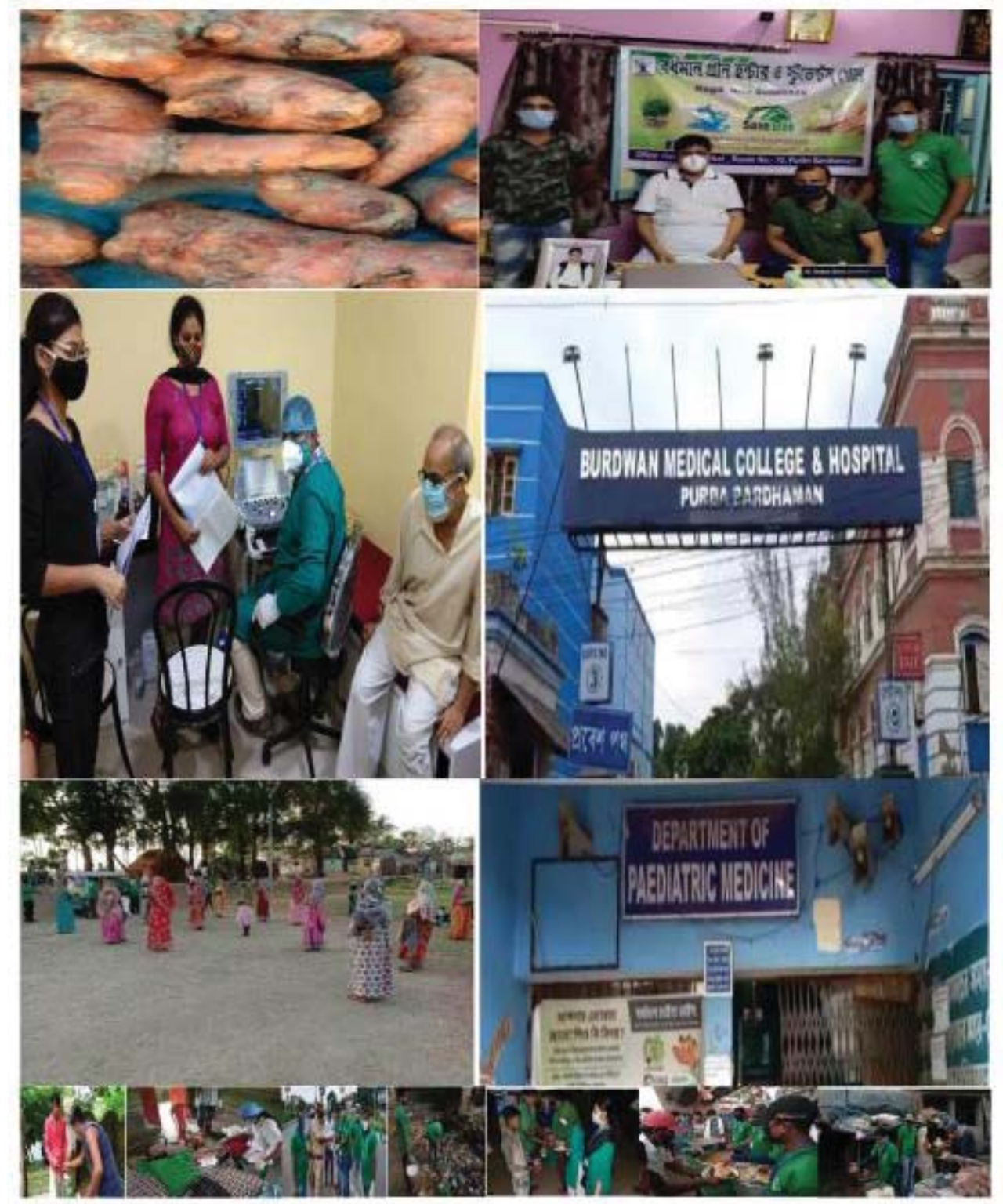


\& Plate 1). All the info were counted for statistical analysis by ' $\mathrm{t}$ '-test $(\mathrm{P}<0.01)[21-56]$

\section{Sample area}

The treatment study areas were carried out by the NGO, at the 11-slam area of Burdwan Municipality and its surrounding, Purba Bardhaman, West Bengal, India, as follows:

- In Burdwan municipality: Five slum area;

1. Kora Basti-67 family with more than 300 population,

2. Bhatchala Kora Para-41 family with more than 250 population,

3. Ichlabad Adibasi Para-315 family with more than 2100 population,

4. Nilpur Adibasi Para-35 family with more than 135 population, and

5. Banmasjid Para-67 family with more than 220 population.

In Burdwan- I: Four slum area;

1. Malirbagan- 350 family with more than 1500 population,

2. Dangapara- 350 family with more than 4500 population,

3. Jhinguti Adivasi para- 45 family with more than 210 population, and

4. Agriculture Farm Borpukur-250 family with more than 1400 population.

- Burdwan-II: Two slum area;

1. Bhatar Chandipur- 137 family with more than 600 population, and

2. Atagarh-250 family with more than $\mathbf{1 1 0 0}$ population (Figure 1 \& Plate 1) $[44,46,47,51,54]$.

\section{Different activity-groups formation and function}

The Burdwan Green Haunter and Students' Goal, NGO, forms four main activity-groups; core group, working group, advisory group, and social media group, headed and coordinated by the secretary, Mr. Rakesh Khan, M.A., B.Ed. (Gold Medalist), and president, Mr. Subhendu Bose, Administrator of B.Ed. College.

- Core Group- has 22-members with 10-subgroup, decision-making, and leading-working group.

- Working Group- has 210-members with 11-subgroup, engaged in different social activities.

- Advisory Group- has 10-members in different disciplines like academicians, administrators, doctors, teachers, scientists, business personalities, engineers, accountant, social reformer, reporter, government employee, and entrepreneur with different-subgroup, give advice and problem solve, if necessary.
- Social-media Group- has more than 1300 members, followers 21,000 , engaged mainly for publicity.

Key note: COVID-19 preventive measures rules and regulation maintained in each activity (Plate 1) [21-56].

\section{Biomedicine turmeric extract preparation}

The sun-dried and powdered sort of rhizomesturmeric, Curcuma longa L., (Plate 1), were extracted with $90 \%$ ethanol at $25 \pm 2{ }^{\circ} \mathrm{C}$ temperature for 15 days and were filtered for collecting extract. Later, the ethanol from the extract was removed by evaporation at temperature $\left(25 \pm 2^{\circ} \mathrm{C}\right)$. The residue was dried in an exceedingly desiccator over anhydrous salt $\left(\mathrm{CaCl}_{2}\right)$, and therefore the crude residue was diluted in $90 \%$ ethanol at $1 \mathrm{mg} / \mathrm{ml}$ concentration and was prepared, Turmeric Extract (TE) or Turmeric MT (TMT) (Original solution or crude extract i.e. Mother Tincture) [22-24,28,29,33,35,37,40,41,44$56]$.

Preparation of Ultra-High-Diluted-Biomedicines-Liquids; Turmeric 30C, Turmeric $200 \mathrm{C}$, and Turmeric $1000 \mathrm{C}$ for future: These biomedicines were prepared by some drops of a liquid potency of Turmeric 30C, Turmeric $200 \mathrm{C}$, and Turmeric 1000C [22-24,28,29,33,35,37,40,41,44-56].

Preparation of Ultra-High-Diluted-Biomedicines-Globules; Turmeric 30C, Turmeric $200 \mathrm{C}$, and Turmeric $1000 \mathrm{C}$ for future: These biomedicine globules were prepared by soaking of the few drops of a liquid potency within the proportion of 7.2 mg globules/ml of Turmeric 30C, Turmeric $200 \mathrm{C}$, and Turmeric $1000 \mathrm{C}[22-24,28,29,33,35,37,40,41,44-56]$.

\section{Treatments}

The treatments and visits were done within the different slum areas of Purba Bardhaman District (Plate 1) under the guidance of the Dr. Subhas Chandra Datta, and the visiting as well as treating doctors of Burdwan Medical College and Hospital and CMO of the Hospital (BMCH and $\mathrm{CMOH}$ ) who only provided rapid antigen kits for the infected and comorbid patients (Table 1). In the 11-slum-area (treatment groups), the community-biomedicine of high-diluted-form, turmeric extract (TE) or turmeric MT, made from the turmericrhizome, Curcuma longa L., is mixed @10-20 drops (1-2mg) / cup (100ml-150ml) of moderately-hot germ-free-drinkingwater, administered orally every-day in the early morning (with an empty-stomach) once/day for thirty-days before illness-onset as a preventive measure, with no need to ethical consideration for the permissible doses and safety concerns, OR may be applied after the symptom-onset against present coronavirus infections as a vaccine, where COVID-19 patients in hospitalized, and also the dose could also be increased looking on the intensity of diseases, and age, just in case of treatment suggested by the doctors, and the young-local-students NGO, the "Burdwan-Green-Haunter-and-Students'-Goal", take initiative for COVID-protocol, social-awareness- and treatment-camp with doctors $\left[22-24,28,29,33,35,37,40,41,44_{-}^{-}\right.$ 56]. 
Table 1: Complete findings of high-diluted TE or TMT on COVID-19 patients and observation of the 2nd phase reinfection of coronavirus-2.

\begin{tabular}{|c|c|c|c|c|c|c|c|c|c|}
\hline \multirow{2}{*}{\multicolumn{2}{|c|}{$\begin{array}{l}\text { Average Treatment } \\
\text { Age Groups (years) }\end{array}$}} & \multicolumn{8}{|c|}{$\begin{array}{l}\text { Treatment and Visited Area: } 11 \text { Slum Arear of Purba Bardhaman (11-09-2020 to 17-07-2021), } \\
\text { And Control Group: Rest of the Area of Purba Bardhaman }\end{array}$} \\
\hline & & $\begin{array}{l}\text { Name \& Number } \\
\text { of the Slum Area }\end{array}$ & $\begin{array}{l}\text { Average } \\
\text { Number of } \\
\text { Family }\end{array}$ & $\begin{array}{c}\text { Average Number } \\
\text { of Family Member } \\
\text { Visited }\end{array}$ & $\begin{array}{c}\text { Average Percent } \\
\text { of COVID-19 } \\
\text { Active Patient }\end{array}$ & $\begin{array}{l}\text { Average } \\
\text { Percent } \\
\text { COVID-19 } \\
\text { Passive }\end{array}$ & $\begin{array}{c}\text { Average } \\
\text { Percent } \\
\text { of Home } \\
\text { Quarantine }\end{array}$ & $\begin{array}{l}\text { Average } \\
\text { Recovery } \\
\text { Percent }\end{array}$ & Remarks \\
\hline \multicolumn{2}{|c|}{$\begin{array}{l}\text { I. Senior Age Group: } \\
\qquad(60-99)\end{array}$} & $\begin{array}{l}\text { Burdwan } \\
\text { Municipality \& } 5 \text { a }\end{array}$ & $1897 \mathrm{c} \pm 00.01$ & $489 b \pm 00.21$ & $46 a \pm 00.04$ & $54 \mathrm{c} \pm 00.02$ & $44 \mathrm{~b} \pm 00.02$ & $94 b \pm 00.02$ & $\begin{array}{c}\text { Died only aged and } \\
\text { comorbid } \\
\text { patients }\end{array}$ \\
\hline \multicolumn{2}{|c|}{$\begin{array}{l}\text { II. Middle Age Group: } \\
\qquad(20-59)\end{array}$} & Burdwan-I \& 4a & $5719 a \pm 00.01$ & $467 c \pm 00.71$ & $34 \mathrm{~b} \pm 00.02$ & $66 b \pm 00.02$ & $89 a \pm 00.03$ & $99 a \pm 00.02$ & \begin{tabular}{|} 
Reinfection occur due \\
to attend \\
in gathering for vote \\
camping
\end{tabular} \\
\hline \multicolumn{2}{|c|}{$\begin{array}{l}\text { III. Early Age Group: } \\
\qquad(00-19)\end{array}$} & Burdwan-II \& 2b & $4699 \mathrm{cb} \pm 00.01$ & $942 \mathrm{a} \pm 00.81$ & $30 c \pm 00.01$ & $70 a \pm 00.02$ & $27 c \pm 00.01$ & $98 a \pm 00.02$ & Sever reinfection occur \\
\hline \multicolumn{2}{|c|}{$\begin{array}{l}\text { Total Age } \\
\text { Groups:(01-99) }\end{array}$} & 11 & 12315 & 1907 & 110 & 190 & 160 & 291 & $\begin{array}{l}\text { Average Recovery- } 98 \% \\
\text { Average Mortality- } 2 \%\end{array}$ \\
\hline \multirow[b]{2}{*}{$\begin{array}{l}\text { Control } \\
\text { Group (01- } \\
99)\end{array}$} & $\begin{array}{c}11-09- \\
2020\end{array}$ & All area & All family & All family members & $333(9.97 \%)$ & $2706(81.04 \%)$ & $645(86.58 \%)$ & $82.06 \%$ & $\begin{array}{l}\text { Average Recovery- } \\
82.06 \% \\
\text { Average } \\
\text { Mortality-1.34\% }\end{array}$ \\
\hline & $\begin{array}{l}17-07- \\
2021\end{array}$ & All area & All family & All family members & $339(75.50 \%)$ & $38035(99.50 \%)$ & 00 & $97.06 \%$ & $\begin{array}{c}\text { Average } \\
\text { Recovery-97.66\% } \\
\text { Average } \\
\text { Mortality-1.16\%, and } \\
30 \text { children died in } \\
\text { MIS-C }\end{array}$ \\
\hline
\end{tabular}

\section{Collection methods of data and maintenance record}

Data collections methods were done directly by the NGO with the observation from 11 areas of slums communities for treatments groups, and also the regular follow of the up-todate web portal of Purba Bardhaman maintaining records for control groups also, and every one the pieces of information were counted for statistical analysis by ' $\mathrm{t}$ '-test $(\mathrm{P}<0.01) \quad[22-$ $24,28,29,33,35,37,40,41,44-56]$.

\section{Observations}

Different behavior and attitude of the communities has been observed by NGO-direct physical access, and every one the information were counted for statistical analysis by ' $\mathrm{t}$ '-test $(\mathrm{P}<0.01)[21-56]$.

\section{Science and technology communication}

The activity of students, teachers, staffs, community, photographers, visitors, and media personnel, campaign, make the news, and publication regarding the importance in Science and Technology Communication in different audiovisual media (TV channels), social media, and journals are recorded [21-56].

\section{Full protocol}

The NGO takes initiatives or emphasis on different protocols (Plate 1), maintaining COVID-19 preventive measures rules and regulations with treatment in the slum areas, as follows [22$24,28,29,33,35,37,40,41,44-56]$ :

- Maintain at least 1 meter (3 feet) physical or social distance between ant two men.
- Way and use and distribution of masks.

- Avoid crowded places or gatherings.

- Regular and thoroughly clean your hands with an alcohol-based sanitizer hand rub or wash with soap and water, and supply.

- Avoid touching eyes, nose, and mouth.

- Follow good respiratory hygiene.

- Way of after coughing or sneezing, dispose of the used tissue immediately and wash hands.

- Way of proper use of specific dustbin.

- Stay home and self-isolate even with minor symptoms such as cough, headache, mild fever, until recovery.

- If fever, cough, and difficulty breathing, seek medical attention, but call by telephone in advance if possible and follow the directions of the local health authority.

- Keep up to date on the latest information from WHO or local and national health portal or authorities.

- Way of consuming nutritious foods and vegetables.

- Adopt strict-lockdown-measures, and COVID-19 rules and regulations.

- Supporting maternal and child health, mental health, or initiatives against domestic violence.

- Arrangement of blood donation camp. 
- Tree-plantation with conservation-biodiversity.

- Different day-celebration.

- Procedure of reduce-economic-activities to a minimum.

- Arrangement of distributing-rations to families in slums, and to providing cooked-meals to migrants.

- Arrangement to ensuring that senior-citizens have medicines.

- Distributing clothes and educational materials.

- Mobile and digital door to door- teaching.

- Arrangement of health checkup camp.

- Arrangement of comprehensive and effective science and health consciousness and communication effort.

- Arrangement of authentic scientific and health information.

- The initiative is targeted at encouraging public participation in risk-related reciprocal communication processes

- Involvement to build capacities and enable communities to develop a sense of awareness, an analytical mind, and a decision.

- Promote personal sanitation and hygiene, physical distancing, and maintaining desired collective behaviors, etc.

- Enhance science coverage in mass media including illustrative interpretations especially to reduce the fear of risks and build confidence with a dose of necessary understanding.

- Inculcate scientific temper for adopting sustainable healthy lifestyles, and nurturing scientific culture among masses and societies.

- Wall- and road- writings, and posturing.

- Arrangement of workshops for preparation of sanitizer and making of mask.

- Online celebration of different day.

- Arrangement of web talk on different issues.

- Arrangement of street-cornering regarding different issues emphasis on humanity in pandemic situation.

- Arrangement of different digital materials for social media.

- Note- All the above-mentioned jobs were done in the 11- slum sample-area of the sample treatments zone.

\section{Results and discussion}

Table 1 and Figure 1; focused on the results of biomedicine of high-diluted-Turmeric Extract (TE), or Turmeric MT (TMT) on patients suffering in COVID-19, and records the reinfection of coronavirus-2 within the study areaof Purba Bardhaman from the 11th September 2020 to 17th July 2021, and every one the information were taken for the statistical analysis by ' $t$ ' -test $(\mathrm{P} \leq 0.01)$, and it absolutely was seen that the senior-aged and comorbid-patients of COVID-19 were infected badly with high death (or mortality) rate than the opposite two age groups in treated 11-slum sample area (Table 1) because of treatment with high-diluted-biomedicine, TE, or TMT, which boosted natural immunity $[1,2,6,24,28,29,33,35,37,40,41,44-56]$. The thirty children are infected to post-COVID-19 Multisystem Inflammatory Syndrome (MIS-C) in the control area. But it absolutely was interesting that under the 20 people showed as passive coronavirus carrier with absolute recovery in the 11-slum sample area, and it had been remarkable that no reinfection occurs within the middle and early cohort of all relations thanks to the consequences of biomedicine, TE or TMT, long-lasting potential immunity because of the presence of potential, effective and active phytochemical-constituents in curcumin of turmeric, etc., are significantly active against COVID-19 [1,2,6$24,28,29,33,35,37,40,41,44-56]$. So, this preventive treatment measures revealed that high-diluted-internal-potential-biomedicine, TE, or TMT, are highly effective in controlling diseases by boosting resistance against coronavirus with no side effects. During the 2nd phase of the pandemic of the 11-slum area of Purba Bardhaman, the "Burdwan Green Haunter, and Students' Goal" -NGO, actively involved for awareness regarding the medication with covid-protocol, and that they also reported that the 2nd phase-COVID-19 reinfection within the slum from the 11th September 2020 to 17th July 2021, no active or severe COVID-19 middle-aged patient is shown within the 11-core-NGO-activity slum, except within the Aatagarh of Burdwan-II, where two MIS-C children of post-COVID-19 positive infection, and admitted within the hospital, and recovered, but out of 30 , one died in another area [1,2,6$24,28,29,33,35,37,40,41,44-56]$. On the opposite hand, within the non-experimental control area (In Figure 1), the COVID-19 report on 11th September 2020 and 17th July 2021, of Purba Bardhaman district, respectively shows that total COVID-19 positive cases are 3339 and 38225, the overall number of discharge cases are 2740 and 37331, and the overall number of COVID-19 death are 45 and 445, rate of recovery is 82.06 attempt to $97.66 \%$, and rate of mortality is $1.34 \%$ and 1.16 respectively, and it's thought that no active or severe COVID-19 patient is shown within the poor 11 slum city area of the Purba Bardhaman District, thanks to high-diluted biomedicine, taking or consuming TE or TMT, followed by all COVID-19 preventive measures rules and regulations maintained in each activity, and slum people have received all variety of facilities provided by the student's NGO, and it confirmed that the local NGO- "Burdwan Green Haunter and Students' Goal", acts as a "Social-Vaccine-COVID-19 Epidemic-Model" by their different human resource creating green effective action for the most effective of humanity to beat COVID-19's spread, transform scientific fieldwork, and protect us all [21,30-32,57-59]. 
For the comparison of achievement or more success, Figure 1 is very important, and it is considered from 11/09/2020 to $17 / 07 / 2021$ by using natural biomedicine of high-diluted-Turmeric Extract (TE), or Turmeric MT (TMT), and improved in all respect of average covid-19 active-and passive-patient recovery $65.53 \%$ to $18.46 \%$ respectively, and total average recovery increased $15 \%$ in general before the 3rd phase of virus attack. Though in the treated 11 slum areas is the achievement most in the poor needy sample area. So, high-diluted-biomedicines Turmeric Extract acts as preventive COVID 19 vaccines achieving community-medicine-public-health-ecology sciencetechnology-innovations.

\section{Future approach in research}

During this new normal situation, and it'll be essential to tell public health-ecology expertise, test, and research, to reopen, and also the present results and discussion fulfill the goal for the long run research suggestions because the current preventive pretreatments with the ultra-high diluted biomedicines; Turmeric MT or Turmeric 30C, Turmeric 200C, and Turmeric $1000 \mathrm{C}$-liquid OR -Turmeric 30C, Turmeric 200C, and Turmeric $1000 \mathrm{C}$ - globules, at extremely ultra-low doses, for potential future research for the subsequent reasons; use as very old traditional medicines, overcome many medical complications, effective for several pharmacological activities, very low toxicity $(\mathrm{LD} 50=3741.7 \mathrm{mg} / \mathrm{kg}$ ) and high efficacy, present of diverse potential phytochemical constitutions, side effects-free, and a few vaccines made up of their ultrahigh-diluted phytoconstituents crossing the Avogadro limit, cost-effective, easily prepare-able, easily available, easily manufacture-able, equitable, marketable and supply-able, etc. and develop the best quality biomedical and life-scientific information on all aspects of pharmacology and its analytical nanoparticles studies or proper side-effects frees effective medicines or drugs also. and therefore the students and "NGO Potential Policy Developer Social-Vaccine-COVID-19Epidemic-Models Against Corona Crisis Achieved Sustainable Development Socio-Economic Welfare Science Technology Innovations, the STIP 2020 by the inclusive design process aims to strategize priorities, sectoral focus, and methods of research and technology development innovation for larger green-socio-economic-welfare, supported the theme "Vision 2040" that might help policymakers, solving the virusinduced slump, transform scientific fieldwork crisis, and also the crisis of over $1 / 4$ of individuals with COVID-19 not fully recovered after 6-8 months within the world also, though India's third wave of COVID-19 could also be in pockets [22$24,28-35,37,40,41,44-61]$. So children should get COVIDvaccines [62].

\section{Future-treatments-and-cures-of-biomedicine-turmeric}

Just before submission of this paper, it's worth mentioning that it's been received the "Greetings from Advances in Agronomy, Plant Breeding and Horticulture through the Hon'ble Associate Editor, Dr. Jessica Watson by email, editor.aapbh@ emedscholar.com on Thursday, 22 July 2021", and writes, "We are happy to tell you that your manuscript has received positive review comments from the reviewer. The Review Com- ments as follows; Biomedicine could be a Western medicine that applies biological and physiological principles to clinical practice. Biomedicine is that the cornerstone of recent health care and laboratory diagnostics. This general field of research includes many areas of both the life and physical sciences. Utilizing biotechnology techniques, biomedical researchers study biological processes and diseases with the final word goal of developing effective treatments and cures within the present manuscript, Dr. Subhas Chandra Datta reconnoiters the "Genetic effects of the biomedicines-Gall MT (GMT) on advanced agronomy-plant-breeding-horticulture-environment socioeconomy green-science-technology-communication-issues by preventing okra root-knot and COVID-19", and this is often a noteworthy study on biomedicines achieving the ' $\mathrm{Na}$ ture's-Gift to Human-Disease-Free-Healthy-Life. Effect of the GMT-pretreated and GMT-post treated on okra plants inoculated with root-knot nematodes and genetic effects of root proteins of the GMT-pretreated and GMT-post treated on okra with nematode proteins were described very well. The paper is usually well written and structured. Overall, the results are clear and that it approve of its publication [10-20,63].

\section{Ethical approval turmeric extract}

The questions may arise regarding "There is no mention of the approval from an ethics committee and taking signed informed consents from participants prior to study initiation". So it is necessary to provide this information. In India over 3,000 years ago, turmeric, primarily use as a culinary spice and traditional Indian ayurvedic medicine, and its most important active ingredient is curcuminoids with effective doses is $500-$ $2,000 \mathrm{mg}$ of turmeric per day, often in the form of an extract with a curcumin concentration that is much higher than the amounts naturally occurring in foods, and the average Indian regular diet provides around 2,000-2,500 mg of turmeric (60-100 mg of curcumin) per day, and the same amount in extract form may pack up to $1,900-2,375 \mathrm{mg}$ of curcumin [64]. And turmeric and conventionally formulated curcumin products are probably safe when taken orally or applied to the skin in the recommended amounts, and it's safe to use turmeric in amounts greater than those commonly found in food while breastfeeding also $[64,65]$. Here, the High-DilutedTurmeric Extract (TE) or turmeric MT, prepared from the turmeric-rhizome, Curcuma longa L., is used as communitybiomedicine@1-2mg in10-20 drops are mixed in cup (100ml$150 \mathrm{ml}$ ) of drinking-water per candidate, administered orally every-day in the early morning @once/day for thirty-days, in the 11-slam-area of Purba Bardhaman District. And the used doses are below the recommended doses. So, automatically it is no need for ethical approval or consideration for the permissible doses and safety concerns or any ethics committee and taking signed informed consents from participants prior to study initiation $[64,65]$.

\section{Conclusions}

It is concluded that the easily-available, easily-suppliable, easily-applicable, side-effects-free, non-toxic, cost-effective, eco-friendly, and easily-preparable, high-diluted-potentialcommunity-biomedicine, Turmeric Extract (TE) or Turmeric 
MT (TMT), may act as preventive policy-developer-potential-21st-century-pandemic COVID 19 vaccine by achieving community-medicine-clinical-research-public-health-ecology-green-socio-economy-welfare-science-innovationstechnology communication-applications-advancements-issues. And within the new normal-future, it would be the foremost effective vaccine by using the ultra-high-diluted type of the community-biomedicines TE against day-to-day new virulent-coronavirus pandemics, oncology, and oral-health and multidisciplinary-care of COVID-19-survivors improving community-immunity or herd-immunity also, and studentsNGO acts as 'Social-Vaccines' by their different human resource creating effective ecology-health activities that specialize in the notice of methods, research, science, and technology development for larger green-socio-economic-welfare, supported the theme "Vision 2040" that might help policymakers, solving virus-induced economic-condition globally.

\section{Acknowledgment}

The work described here has been supported by the graduate and post-graduate students, guardians, and community, photographers, visitors, and media personnel. I express my deep gratitude to thanks Mr. Rakesh Khan, M.A., B.Ed., (Gold Medalist), Secretary, and Mr. Subhendu Bose, Administrator, President, and each one green-members of Burdwan Green Haunter and Students' Goal for helping me for arranging several awareness programs regarding Science and Technology Communication Bio-diversity issue. I'm thankful to the eminent Senior Consultant Physician \& Cardiologist Dr. Tushar Kanti Batabyal, M.B.B.S., M.D., Ex-Clinical Tutor of the Burdwan Medical College \& Hospital, for inspiration and guidance. Last but not the least; I'm thankful to the eminent educationist Sri Tapaprakash Bhattacharya for inspiration and guidance.

\section{References}

1. Hennon TR, Penque MD, Abdul-Aziz R, Alibrahim OS, et al. (2020) COVID-19 associated Multisystem Inflammatory Syndrome in Children (MIS-C) guidelines; a Western New York approach. Progress in Pediatric Cardiology 57: 101232. Link: https://bit.ly/3AJDlhn

2. Couzin-Frankel J (2021) Will COVID-19 change science? Past pandemics offer clues. Science Health Coronavirus. Link: https://bit.ly/2VRIMwl

3. MNT News Team (2021) COVID-19 live updates: Total number of cases passes 188 million. MNT News on July 16, 2021.

4. The Government of India (2020) As India and the world reorient in the wake of the COVID-19 crisis, a landmark policy initiative has been flagged by the Government of India. The Science, Technology and Innovation Policy, 2020 (STIP2020). https://www.mygov.in/campaigns/stip-2020/.

5. The Government of India (2020) Government of India is taking all necessary steps to ensure that we are prepared well to face the challenge and threat posed by the growing pandemic of COVID 19 - the Corona Virus. Link: https://bit.ly/3y038UU

6. Nalbandian A, Sehgal K, Gupta A, Madhavan MV, McGroder C, et al. (2021) Post-acute COVID-19 syndrome. Nat Med 27: 601-615. Link: https://go.nature.com/3ilVmWK

7. Dasgupta M (2018) Neurotoxicity, Immunotoxicity and Drug Toxicity - A Review. Adv Clin Toxicol 3: 000S1-001. Link: https://bit.ly/3iEtpiW
8. Babaei F, Nassiri-AsI M, Hosseinzadeh H (2020) Curcumin (a constituent of turmeric): New treatment option against COVID-19. Food Sci Nutr 8: 52155227. Link: https://bit.ly/2UbOM1s

9. Hosseini A, Hosseinzadeh H (2018) Antidotal or protective effects of Curcuma longa (turmeric) and its active ingredient, curcumin, against natural and chemical toxicities: A review. Biomed Pharmacother 99: 11-421. Link: https://bit.ly/3xKWiOF

10. Emirik M (2020) Potential therapeutic effect of turmeric contents against SARS-CoV-2 compared with experimental COVID-19 therapies: in silico study. J Biomol Struct Dyn 1-14. Link: https://bit.ly/3jTLpFc

11. Manoharan Y, Harida V, Vasanthakumar KC, Muthu S, Thavoorullah FF, et al. (2020) Curcumin: a Wonder Drug as a Preventive Measure for COVID19 Management. Ind J Clin Biochem 35: 373-375. Link: https://bit.ly/3iFM4KZ

12. Rajagopal K, Varakumar P, Baliwada A, Byran G (2020) Activity of phytochemical constituents of Curcuma longa (turmeric) and Andrographis paniculata against coronavirus (COVID-19): an in silico approach. Future $\mathrm{J}$ Pharmaceutical Sci 6: 104. Link: https://bit.ly/3jJFW3G

13. Kritis P, Karampela I, Kokoris S, Dalamaga M (2020) The combination of bromelain and curcumin as an immune-boosting nutraceutical in the prevention of severe COVID-19. Metabol Open 8: 100066. Link: https://bit.ly/3CTuprF

14. Dhar S, Bhattacharjee $P$ (2021) Promising role of curcumin against vira diseases emphasizing COVID-19 management: A review on the mechanistic insights with reference to host-pathogen interaction and immunomodulation. J Funct Foods 82: 104503. Link: https://bit.ly/2VR940s

15. Rattis BAC, Ramos SG, Celes MRN (2021) Curcumin as a Potential Treatment for COVID-19. Front Pharmacol 12: 675287. Link: https://bit.ly/3fVyNfG

16. Dourado D, Freire FT, Pereira DT, Amaral-Machado L, Alencar EEVN, et al. (2021) Will curcumin nanosystems be the next promising antiviral alternatives in COVID-19 treatment trials? Biomed Pharmacotherapy 139: 111578. Link: https://bit.ly/3IVRns1

17. Jena AB, Kanungo N, Nayak V, Chainy GNB, Dandapat J (2021) Catechin and curcumin interact with $S$ protein of SARS-CoV2 and ACE2 of human cell membrane: insights from computational studies. Sci Reports Nat 11: 2043. Link: https://go.nature.com/2VJYER6

18. Roberts N, Brown RE, Buja LM, Weerasinghe P (2020) Molecular Mechanisms of Curcumin in COVID-19 Treatment and Prevention: A Global Health Perspective. Med Res Archives 8: 1-22. Link: https://bit.ly/2Xpvh71

19. Miryan M, Bagherniya M, Sahebkar A, Soleimani D, Rouhani MH, et al. (2020) Effects of curcumin-piperine cosupplementation on clinical signs, duration, severity, and inflammatory factors in patients with COVID-19: a structured summary of a study protocol for a randomised controlled trial. Trials 21: 1027. Link: https://bit.ly/3AEVE7m

20. Prasad S, Aggarwal BB (2011) Turmeric, the Golden Spice: From Traditional Medicine to Modern Medicine. CRC Press 2011: 310. Link: https://bit.ly/3IUbZkm

21. Datta SC (2020m) NGO Act as Potential-Policy-Developer Social-VaccineCOVID-19 Epidemic-Model until Discovery-of-Medical-Vaccine: Achieved Green-Socio-Economic Welfare Science Technology Innovations. Arch Community Med Public Health 6: 225-232.

22. Datta SC (2020) Enriched Science and Technology Communication Economy in Agriculture by Use of Acacia sides as Potential Bio-Agents against Various Pathogens. Advances in Agriculture, Horticulture and Entomology 2: 1-13. Link: https://bit.ly/3CJvMsx

23. Datta SC (2020b) Acacia auriculiformis-Extract Synthesis PR-Proteins Developed Potential Biomedicines-Vaccine against Okra-Diseases and 
COVID-19: Improved Science Technology Communications Bio-Economy Applications. International Journal of Research-GRANTHAALAYAH 8: 249270. Link: https://bit.ly/37CNIXs

24. Datta SC (2020c) Cina-Pretreatments Act as Potential-BiomedicineVaccine against COVID-19 and Okra-Plant-Diseases: Synthesis PR-Proteins Increased-Immunity Improved Biomedicines-Economy Applications ScienceTechnology-Communications. International Journal of Ayurveda 5: 05-26. Link: https://bit.ly/3IUbYgi

25. Datta SC (2020d) Okra Maybe Potential Cost-Effective PersonalizedBiomedicines Social-Vaccine against COVID-19: Improved Immunity Food-Security Green-Economy Science-and-Technology-Communication Applications. Innovative Journal of Medical Sciences 4: 5-20. Link: https://bit.ly/37AABpY

26. Datta SC (2020e) Intercropped Cowpea Maybe Use as Biomedicine Improved Immunity against COVID-19: Enriching Science and Technology Communication Applications Food Security Economy. Diagnosis and Therapies Complementary and Traditional Medicine 35-48.

27. Datta SC (2020f) Weeds-Vegetables and Fruits Act as Potential Biomedicines against COVID-19: Enriched Agriculture Biodiversity Socio-Economy Science Technology Communications by Controlling Plants Diseases. Journal of Experimental Biology and Agricultural Sciences 8: S139-S157. Link: https://bit.ly/3jWZQbU

28. Datta SC (2020g) Biomedicines-Aakashmini Cost-Effective COVID-19 vaccine: Reduced Plant-Diseases Enriched Science Technology Communications Socio-Economy Bio-Applications. Global Journal of Bioscience and biotechnology 9: 127-144

29. Datta SC (2020h) Discovery of COVID-19 Vaccine by Using Acaciades as a Phytomedicine Improving Science and Technology Communication Applications- An Ideas. Open Access Journal of Biogeneric Science and Research 2: 1-30. Link: https://bit.ly/3m09qNy

30. Datta SC (2020i) Improved Science and Technology Communications: Barn Owl Act As Social Vaccine Against COVID-19. International Journal of Latest Research in Science and Technology 9: 6-13. Link: https://bit.ly/2VIY1qp

31. Datta SC (2020j) Potential Policy-Developed Global-COVID-19-Vaccine Enriched Medical Sciences and Technology Green-Socio-Economy. Cross Current International Journal of Medical and Biosciences 2: 143-154.

32. Datta SC (2020k) Improved midday meal by using cowpea as eco-friendly crop controlling root-knot forming global, green, growth and green economy. International Journal of Advanced Research 9: 6-13. Link: https://bit.ly/3IWOV4j

33. Datta SC (2020I) Biomedicines-Cina against COVID-19: Controlled Plant Diseases Enriched Science and Technology Communication Green Economy. The International Journal of Research -GRANTHAALAYAH 8: 234-255

34. Datta SC (2020n) Biological and BioSystems Engineering Barn Owl Controlled COVID-19: Engineering Bio-mechanical Biomedical Science Technology Communication Enriched Agriculture Environment. International Journal of Engineering and Science Invention 2319 - 6734.

35. Datta SC (2020c) Cina-Pretreatments Act as Potential-Biomedicine-Vaccine against COVID-19 and Okra-Plant-Diseases: Synthesis PR-Proteins Increased Immunity Improved Biomedicines-Economy Applications Science-TechnologyCommunications. International Journal of Ayurveda 5: 05-26. Link: https://bit ly/3sa2MWc

36. Datta SC (2020p) Artificial-Nest Rainwater-Harvesting with Fishery and Floating-or-Rooftop-Gardening Act as $21^{\text {st }}$ Century Civil-Engineering COVID-19 Epidemic-Model: Improved Biodiversity Agriculture SocioEconomic Environmental-Sciences Technology-Communication. Journal of Civil Engineering and Environmental Sciences 6: 022-036. Link: https://bit.ly/3ylbCNI

37. Datta SC (2020q) Homeopathic Medicines Aakashmoni Will Be the Best
Vaccine Against COVID-19: Enriching Agriculture Science and Technology Communication Mechanism Application Issues. International Journal of Research GRANTHAALAYAH 8: 333-361. Link: https://bit.ly/3fYzvZN

38. Datta SC (2021b) Weed-Plant Act as Vaccine against Plant-and-COVID-19 Diseases: Enriched-Agriculture-Health-Development Socio-Economy SciencesTechnology-Communication-Application. International Journal of Pharmaceutical Sciences and Clinical Research 1(1):1-17.

39. Datta SC (2021c) Weed-Plant Act as Vaccine against Plant-and-COVID-19 Diseases: Enriched-Agriculture-Health-Development Socio-Economy Sciences-Technology-Communication-Application. International Jour nal of Pharmaceutical Sciences and Clinical Research 1: 1-17. Link: https://bit.ly/37BzrKK

40. Datta SC (2021d) Immediate apply cost-effective easily preparable-available $21^{\text {st }}$ century potential -ayurvedic-herbal-integrative-medicine-vaccine of COVID-19: achieved agriculture healthcare-socio-economy science technology communication mechanism! Int. J. Res.-Granthaalayah 9: 227-247. Link: https://bit.ly/2UhyK6q

41. Datta SC (2021e) High-Diluted Pharmacological-Potential Biomedicines Prevent $21^{\text {st }}$ Century COVID-19 Like Pandemic: Improved Drugs-Research Biodiversity Agriculture Socio-Economy. Edit Am J Phar 4: 1031. Link: https://bit.ly/3jU2WwW

42. Datta SC (2021f) Amaranth Plant Protects Climate-Health-Development Socio-Economy Sciences-Technology-Communication: Act as Potential Biomedicine-Vaccine against Plant and 21st Century-Epidemic COVID-19 Diseases. Exp Opin Env Biol 10: 1. Link: https://bit.ly/3xIUtBZ

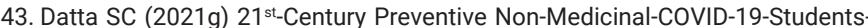
Model: Improved Med Life Clinics Sciences Technology Communication. Med Life Clin 3: 1029. Link: https://bit.ly/3CMvSzF

44. Datta SC (2021h) Dinna Nath Das-Middle English School and -Dispensary Act As a Model: The 21st-Century-Coronavirus-2 Resistance-FuturisticCommon-Ecofriendly-Complex-Green-Digital-School-Health-Ecosystem by Bio-Medicine-Vaccine-Nationalism-Equity-Passport. SunText Rev. Arts Social Sci 2 : $117-224$

45. Datta SC (2021i) Emergency Application of Ultra-High-Diluted-Biomedicines as Vaccine-Nationalism-Equity-Passport Preventing-Coronavirus-2: Developed Medical Health Clinical Research Science Technology Communications Medico Res Chron 8: 132-135. Link: https://bit.ly/3sbT4m9

46. Datta SC (2021j) Vaccine-Passport Bio-Medicinal-Meals Prevent ReinfectionCoronavirus-2: Improved Global-Health-Clinical-Drug-Discovery-EducationResearch Socio-Economy-Science-Technology-Communication-Applications Aditum Journal of Clinical Biomedical Research 2: 1-7.

47. Datta SC, Mukherjee R (2021) High-Diluted-Potential-Internal-Biomedicines Zingiber officinale Extract Prevent 21st-Century Pandemic: Enriched Drugs Health Socio-Economy! United Journal of Internal Medicine 1 : 1-4. Link: https://bit.ly/3fXF8XY

48. Datta SC (2021k) Nematode Extract and Acaciasides Use as Preventive Biomedicines Against Plant Diseases: Improved Earth-Environmental-HealthResearch Science-Technology-Communication and May be Controlled $21^{\text {st }}$ Century Pandemic Diseases. Eart Envi Scie Res Rev 4: 55-60. Link: https://bit.ly/3xIUp5d

49. Datta SC (2021I) Animal-Biomedicine Controls Root-Knot-Disease in LentilCallus-Culture: Enriched Advanced-Clinical-Toxicology Socio-Economy Science-Technology-Communication by Preventing 21 $1^{\text {st }}$-Century-COVID-19 Like-Pandemic-Diseases. Advances in Clinical Toxicology 6: 000214. Link: https://bit.ly/2UdUkZn

50. Datta SC (2021m) Biomedicines Suppress Root-knot Disease of Tomato and Coronavirus-Like-Pandemic-Diseases: Improved Agriculture GreenSocio-Economy Aquatic-Science-Technology-Communication!. Journal of Agriculture and Aquatic Science 1: 08-10.

Citation: Datta SC (2021) High-Diluted-Biomedicines Turmeric Extract (TE) act as Preventive Policy- Developer-Potential-21st-Century-Pandemic COVID 19 Vaccines Achieved Community-Communication-Medicine-Science-Applications-Public-Health-Ecology-Green-Technology-Innovations-Economy-Social-Welfare-Issues! Arch Community Med Public Health 7(2): 164-174. DOI: https://dx.doi.org/10.17352/2455-5479.000157 
51. Datta SC (2021n) Vaccine-Passport Bio-Medicinal-Meals Prevent ReinfectionCoronavirus-2: Improved Global-Health-Clinical-Drug-Discovery-EducationResearch Socio-Economy-Science-Technology-Communication-Application! Aditum Journal of Clinical and Biomedical Research 2: 1-7.

52. Datta SC (20210) Enriched Agriculture Horticulture Science Technology Socio-Economy-Communication-Issue by Biomedicines Suppressing TomatoDisease and Coronavirus2-Like-Pandemic-Diseases! Journal of Agriculture and Horticulture Research. 4(2):74-77.

53. Datta SC (2021p) Genetic Basis of Nematode Extract May Be PreventiveBiomedicines Against Coronovirus-2 by Controlling Root-Knot-Disease of Cowpea-Root-Callus: Enriched Agriculture Clinical Medical-ScienceTechnology-Communications. Global Journal of Clinical and Medical Case Reports 1: 010-018. Link: https://bit.ly/3IZxcJF

54. Datta SC (2021q) Sustainable Reopening of School Preventing ReinfectionCoronavirus 2 in New-Normal by Vaccine-Nationalism-Equity-Passport with Ginger-Drinks-Bio-Medicinal-Mid-Day-Meals. International Journal of Research-Granthaalayah 9: 165-170. Link: https://bit.ly/2VS8T5B

55. Datta SC (2021r) Potential-Biomedicines Against COVID-19: Enriched Food Security Sustainability Agriculture-Biodiversity Socio-Economy ScienceTechnology-Communication-Application-Issues by Preventing Root-Callusand Plant-Diseases! Advances in Food Security and Sustainability: COVID-19 and Food Security edited by Dr. Marc Cohen. Elsevier (Confirmed as Book Chapter) Potential-Biomedicines Against COVID-19: Enriched Food-Security Sustainability Agriculture-Biodiversity Socio-Economy Science-TechnologyCommunication-Application-Issues by Preventing Root-Callus-and PlantDiseases! Advances in Food Security and Sustainability

56. Datta SC (2021s) Animal-Biomedicines Prevent Disease of Tomato and Coronavirus-Like-Pandemic-Diseases: Enriched Agriculture Socio-Economy Science-Technology-Communication-Issues. Merit Research Journal of Microbiology and Biological Sciences 9: 1-4.
57. Datta SC (2021t) Only Environmental Science Act as Natural Bio-medicine Preventive Epidemic Model of 21st Century Pandemic Diseases. Editorial Environ Sci Ind J 17 :e177. Link: https://bit.ly/3yDRegh

58. Datta SC (2021u) Students Act as 21st Century Preventive-PandemicCOVID-19 Model: Improved Advance-Clinical-Toxicology Biomedicine GreenSocio-Economy Science-Technology-Innovations. Advances in Clinical Toxicology 6: 000204. Link: https://bit.ly/3AyEgRs

59. Pennisi E (2021) How COVID-19 has transformed scientific fieldwork. Science Posted in: Scientific Community, Coronavirus. Link: https://bit.ly/3CJvstP

60. Norris $\mathrm{J}$ (2021) More than a quarter of people with COVID-19 not fully recovered after 6-8 months. M.N.T. July 19, 2021.

61. Srivastava V (2021) India's third wave of COVID-19 may be in pockets. Nature India. Link: https://go.nature.com/3g0tsnh

62. Ledford H (2021) Should children get COVID vaccines? What the science says. Nature. Link: https://go.nature.com/3CLN7kE

63. Datta SC (2021v) Genetic effects of the biomedicines Gall MT (GMT) on advanced agronomy-plant-breeding-horticulture-environment socio-economy green-science-technology-communication-issues by preventing okra rootknot and COVID-19! Advances in Agronomy, Plant Breeding and Horticulture.

64. NIH (National Institutes of Health) (2020) Turmeric. Last Updated: May 2020 Link: https://bit.ly/2UhyGUe

65. Amalraj A, Pius A, Gopi S, Gopi S (2016) Biological activities of curcuminoids, other biomolecules from turmeric and their derivatives - A review. J Tradit Complement Med 7: 205-233. Link: https://bit.ly/2VQQIgO

\section{Discover a bigger Impact and Visibility of your article publication with}

\section{Peertechz Publications}

\section{Highlights}

* Signatory publisher of ORCID

* Signatory Publisher of DORA (San Francisco Declaration on Research Assessment)

* Articles archived in worlds' renowned service providers such as Portico, CNKI, AGRIS, TDNet, Base (Bielefeld University Library), CrossRef, Scilit, J-Gate etc.

* Journals indexed in ICMJE, SHERPA/ROMEO, Google Scholar etc.

* OAI-PMH (Open Archives Initiative Protocol for Metadata Harvesting)

* Dedicated Editorial Board for every journal

* Accurate and rapid peer-review process

* Increased citations of published articles through promotions

* Reduced timeline for article publication

Submit your articles and experience a new surge in publication services (https://www.peertechz.com/submission).

Peertechz journals wishes everlasting success in your every endeavours.

Copyright: (c) 2021 Datta SC. This is an open-access article distributed under the terms of the Creative Commons Attribution License, which permits unrestricted use distribution, and reproduction in any medium, provided the original author and source are credited.

Citation: Datta SC (2021) High-Diluted-Biomedicines Turmeric Extract (TE) act as Preventive Policy- Developer-Potential-21st-Century-Pandemic COVID 19 Vaccines: Achieved Community-Communication-Medicine-Science-Applications-Public-Health-Ecology-Green-Technology-Innovations-Economy-Social-Welfare-Issues! Arch Community Med Public Health 7(2): 164-174. DOI: https://dx.doi.org/10.17352/2455-5479.000157 